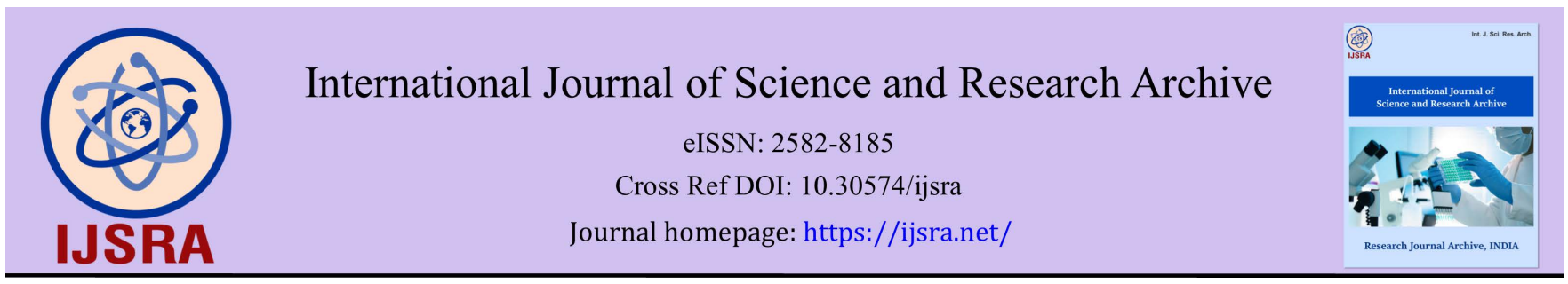

(RESEARCh ARTiCle)

\title{
Influence of discipline and working period on employee performance at PT Yugier Care Indonesia
}

\author{
Abdul Rahman ${ }^{1 *}$ and Muhammad Yusuf ${ }^{2}$ \\ ${ }^{1}$ Department of Development Economics, College of Economics, YAPTI Jeneponto, Jalan M Ali Gassing No 1, Jeneponto, \\ South Sulawesi, 92315, Indonesia, \\ ${ }^{2}$ Department of Fisheries Agrobusiness, Cokroaminoto University Makassar, Jl. Perintis Kemerdekaan Km 11, amalanrea \\ Makassar, South Sulawesi, 90245 Indonesia.
}

International Journal of Science and Research Archive, 2021, 03(02), 123-127

Publication history: Received on 25 August 2021; revised on 29 September 2021; accepted on 01 October 2021

Article DOI: https://doi.org/10.30574/ijsra.2021.3.2.0149

\begin{abstract}
Human resource management is very important in achieving the company's goals. The growth and development of a business or company will be highly determined and influenced by human resource management including human resource management in it. The research was conducted on employees of PT. Yugier Care Indonesia. The type of data used in research is primary data sourced from respondents' answers to a number of questions related to research variables. Research variables include; disipli (X1), working life (X2) and sales performance (Y). The data collection method used by this research data is a survey method with structured interview techniques. The data analysis techniques used in this study are multiple regeresi analysis, $t$ test ( $t$-test) and $F$ (Anova) test. The results concluded that the two variables (factors) namely discipline (X1) and working period (X2) partially or individually have no influence on sales performance at PT. Yugier Care Indonesia, but simultaneously (together) the two variables have a significant (significant) influence.
\end{abstract}

Keywords: Discipline; Tenure; Performance; Employees.

\section{Introduction}

Human resources commonly abbreviated as HR is the main driving factor of the organization or company [1]. Furthermore, according to [2] that the growth and development of a business or company will be greatly determined and influenced by human resources including human resource management in it. HR management is a strategic approach to skills, motivation, development, and resource organizing management [3]. Furthermore [4] is an MSDM is a planning, organizing, implementation and supervision of procurement, development, service delivery, integration, maintenance, and separation of labor in order to achieve organizational goals. Furthermore, according to [5] stated that human resource management contains four objectives, namely; 1) Social goals, 2) Organizational Goals, 3) Functional Goals, and 4) Individual Goals.

Human resource management is very important in achieving the company's goals [6]. Further [7] that the survival of the company depends on the extent to which the company is able to take advantage of opportunities and overcome threats from the external environment with all the potential of the resources at its disposal. The availability of quality human resources is an invaluable asset for the company [8]. Therefore, the company must strive to obtain and place a workforce that is in accordance with their respective areas of expertise so that the company's goals can be realized. The success of a company is greatly influenced by the individual performance of its employees [9]. Every company will

\footnotetext{
* Corresponding author: Abdul Rahman

Departement of Development Economics, College of Economics, YAPTI Jeneponto, Jalan M Ali Gassing No 1, Jeneponto, South Sulawesi, 92315, Indonesia.
}

Copyright (c) 2021 Author(s) retain the copyright of this article. This article is published under the terms of the Creative Commons Attribution Liscense 4.0. 
always strive to get the best performance from its employees. This becomes an inevitability and reasonable considering that only with high employee performance, the company's goals will be easily achieved. Performance is the result of work in quality and quantity achieved by an employee in carrying out his responsibilities. According to [10] that in general human resource management has a role in the company to ensure that the organization is able to achieve success through others. Human resources or employees for a company in the form of their involvement in a plan, system, process and goals that the company wants to achieve.

There are several factors that can affect employee performance, among others; motivation, discipline, compensation (reward), working period and so on. Employee discipline is one aspect that the company always strives to improve. Through work discipline, order is maintained and the implementation of each task will be smooth [11]. Without high work discipline it is difficult for companies to succeed. As mentioned, the working period also affects employee performance. Working time is the time a person works. Generally, employees whose tenure is long enough in the company, he has a lot of experience in carrying out his duties. The long working period of employees certainly affects the quality of work. The quality of this employee's work leads to improvements in their performance. According to [12] work discipline is a form of compliance or obedience of employees / employees in implementing work regulations in the form of oral or written from groups and organizations. Meanwhile, according to [4], work discipline is interpreted as an embodiment of management implementation to strengthen organizational guidelines. According to [13] work discipline is an attitude of respect, respect, and obeying the rules that apply both written and unwritten and able to carry it out, not evading sanctions if it violates the duties and authority given to him. Therefore, it is important to know the factors that affect employee performance in order to achieve the goals of the company / institution.

\section{Material and methods}

\subsection{Data types and sources}

The type of data used in research is primary data sourced from respondents' answers to a number of questions related to research variables. Primary data is data obtained directly from the research subject either in the form of data or information using established guidelines [14].

\subsection{Collecting Data}

The data collection method used by this research data is a survey method with structured interview techniques. According to [15] that surveys are a method of research conducted by asking several questions to people (respondents) about opinions of questions asked.

\subsection{Data analysis}

The data analysis techniques used in this study are multiple regeresi analysis, t test ( $\mathrm{t}$-test) and F (Anova) test. Multiple linear regression analysis is a form of linear regression analysis in which the free variable is more than one, and can be used to measure the effect of a free variable on its bound variable [16]. The tool used in data analysis is to use the SPSS program [17].

\section{Results and discussion}

\subsection{Multiple Regression Analysis}

Multiple linear regression analysis is intended to analyze the relationship in a linear manner between two independent variables namely the discipline variable (X1), and the working life variable (X2), with the dependent variable i.e. sales performance (Y). Based on the results of regression analysis obtained a constant value or $a=5,230$, a value of $b 1=4,170$ and $a$ value of $b 2=0.880$. The regression equation is as follows::

$$
Y=5,230+4,170 X_{1}+0,880 X_{2}
$$

The equation above shows that the value of sales performance without the influence of discipline and working life is 5,230 . While the influence of discipline is 4,170 which means that each increase of 1.0 points, it will increase sales performance by 3,170 points, while the influence of working life will increase by about 0.880 or lower than the influence of discipline. 
Sales performance can actually be measured through discipline and employee tenure. Performance is a result / output of work produced by someone to achieve the expected target / goal. [4] stated that performance is the result of work in quality and quantity achieved by an employee in carrying out his duties in accordance with the responsibilities given to him. A high level of discipline, such as high compliance and attendance, can improve a company's performance. Furthermore, [18] discipline is interpreted as an attitude, behavior and actions in accordance with applicable regulations [19]. High work discipline from employees will have a positive impact on achieving effectiveness and efficiency of work.

\subsection{T-test analysis}

The t-test is intended to test whether each independent variable has a relationship with its bound variable (dependent variable). The t-test is intended to answer the first hypothesis that has been built before, namely; There is a disciplinary influence (X1) on sales performance (Y) and there is an effect of working life (X2) on sales performance (Y). The results of the t-test analysis are obtained as follows::

Table 1 Test Analysis Output t (partial)

\begin{tabular}{|c|c|c|c|c|c|c|}
\hline \multirow{2}{*}{\multicolumn{2}{|c|}{ Model }} & \multirow{2}{*}{$\begin{array}{l}\text { Unstandardized Coefficients } \\
\text { B }\end{array}$} & \multicolumn{2}{|c|}{ Standardized Coefficients } & \multirow[t]{2}{*}{$\mathbf{t}$} & \multirow[t]{2}{*}{ Sig. } \\
\hline & & & Std. Error & Beta & & \\
\hline \multirow[t]{3}{*}{1} & (Constant) & 6.035 & 4.063 & & 1.521 & 0.230 \\
\hline & Disiplin $\left(\mathrm{X}_{1}\right)$ & 3.275 & 1.470 & 0.214 & 3.011 & 0.012 \\
\hline & Masa Kerja $\left(\mathrm{X}_{2}\right)$ & 0.861 & 0.215 & 0.551 & 2.640 & 0.023 \\
\hline
\end{tabular}

The results of the t test analysis found that the discipline variable $\left(\mathrm{X}_{1}\right)$ has a significance value $(\operatorname{Sig} .=0.012<0.05)$ which means accept $\mathrm{H}_{0}$ and reject $\mathrm{H}_{1}$ or in other words there is a significant relationship between the discipline variable $\left(\mathrm{X}_{1}\right)$ to the sales performance variable (Y). This is also reinforced by the result of $t$-count $=3,011>2.028$ which is the value of the t-table. The same thing also happens in the working life variable $\left(\mathrm{X}_{2}\right)$ which also has a significance value (Sig. $=0.022<0.05$ ) which means that the working period variable also affects the sales performance of companies at PT Yugier Care Indonesia. Thus it can be concluded that individually (partially) both free variables have a noticeable (significant) influence on sales performance variables.

This allows this to happen considering discipline as an ideal state in supporting the implementation of tasks in accordance with the rules in order to support work optimization [20]. Furthermore [21] mentioned that one of the conditions for discipline to be grown in the work environment is with a clear division of labor (jobs description), so that everyone knows and is aware of what the task and function is. For this reason, discipline must be developed in order to grow order and efficiency. The results showed that work discipline has a positive influence on employee performance. This is in accordance with the statement by [22] that work discipline is part of the performance factor.

\subsection{Test Analysis F (Anova)}

The F (Anova) test is a simultaneous or simultaneous test between 2 (two) free variables (X) or more against bound variables (Y). In other words, the influence exerted is the influence of the free variables together, in this case the discipline variable (X1) and the working life variable (X2) to the sales performance variable (Y) in the company PT. Yugier Care Indonesia. The results of the F (Anova) test analysis are obtained as follows:

Table 2 F Test Output (simultaneous)

\begin{tabular}{|l|l|l|l|l|l|l|}
\hline \multicolumn{2}{|l|}{ Model } & Sum of Squares & Df & Mean quare & F & Sig. \\
\hline \multirow{2}{*}{1} & Regression & 50.195 & 2 & 25.049 & 14.095 & 0.000 \\
\cline { 2 - 7 } & Residual & 60.294 & 36 & 2.680 & & \\
\cline { 2 - 7 } & Total & 110.489 & 38 & & & \\
\hline
\end{tabular}

Based on the results of the F (Anova) test as tabled above, it was obtained that the significance value (Sig. $=0.000)$ is smaller than the value of alpha $=0.05$, which means reject $\mathrm{HO}$ and accept $\mathrm{H}_{1}$ or in other words there is a significant 
relationship between the discipline variable $\left(\mathrm{X}_{1}\right)$ and the working period variable $\left(\mathrm{X}_{2}\right)$ simultaneously (simultaneously) to the sales performance variable $(\mathrm{Y})$. This is also reinforced by the result of $\mathrm{F}$-count $=14.095$ which is greater than the value of F-table $=3.2500$. Thus, it can be concluded that the two free variables namely discipline $\left(\mathrm{X}_{1}\right)$ and working life $\left(\mathrm{X}_{2}\right)$ together (simultaneously) affect the bound variables, namely sales performance $(\mathrm{Y})$.

According to Sutrisno (2010) that there are several factors that affect employee performance, among others; 1 ) authority or authority and responsibility, 2) discipline, and 3) initiative. Furthermore, it is stated that the disciplinary factors that exist in the company, both superiors and subordinates will give a pattern/color to the company's performance. Organizational performance will be achieved if the performance of individuals and groups is improved. According to [9] argues that discipline is the awareness and willingness of a person to obey all company regulations and social norms that apply. Thus, with high discipline including employee attendance (sales) it will have a direct impact on its performance (sales). According to Rivai (2004), that one indicator of work discipline is attendance. This is a fundamental indicator of discipline, and usually employees who have low work discipline are accustomed to being late for work. Helmi (1996) formulated the factors that affect work discipline into two factors, namely personality factors and environmental factors. While [23] mentioned that work discipline is one of the factors that can affect employee performance. Work discipline is a form of mental attitude from within an employee that becomes one of the factors that affect performance [24]. Similarly, [25] proposed several things that can be influenced by discipline, among others: structuring common life, building personality, training personality, coercive function, punishment function, and creating function.

Similarly, the working period shows a significant influence on sales performance. Education level and working life have a significant effect on employee performance, where teacher tenure variables contribute $35.4 \%$ to teacher performance variables. Long before [23] had also suggested that the working period and adequate level of education for an educator, would more or less affect the performance possessed. Furthermore, it is mentioned that past experience will be very useful in supporting the knowledge that a person has in dealing with new problems..

\section{Conclusion}

Research results obtained; 1 ) The double linear regression equation obtained against the disciplinary variable (X1) and the working life variable $(\mathrm{X} 2)$ to the sales performance variable $(\mathrm{Y})$ is $\mathrm{Y}=5,230+4,170 \mathrm{X} 1+0.880 \mathrm{X} 2+\mathrm{e}, 2)$ The results of the first hypothesis test are obtained that there is no real (insignificant) influence between the discipline variable (X1) and the sales performance variable (Y), 2) The results of the second hypothesis test are obtained that there is no noticeable (significant) influence between the working period variable (X2) and sales performance (Y), and 3) The results of the third hypothesis test found that there is a noticeable (significant) influence together (simultaneously) between the discipline variable (X1) and the working period (X2) on sales performance (Y). Thus it can be concluded that the two variables (factors) namely discipline (X1) and working life (X2) partially or individually have no influence on sales performance at PT Yugier Care Indonesia, but simultaneously (together) both variables.

\section{Compliance with ethical standards}

\section{Acknowledgments}

\section{Acknowledgments}

Thank you for the collaboration between the two universities, namely; Economics College of YAPTI Jeneponto and Cokroaminoto University Makassar. Thank you to the chairman of PT. Yugier Care Indonesia in Makassar and staff for cooperation during the research took place.

\section{Disclosure of conflict of interest}

In principle we do not have a conflict of interest, considering our role and field of study which is different.

\section{Statement of informed consent}

All information and statements obtained from respondents (informants) are for research purposes and will be maintained. 


\section{References}

[1] Kesumawati . Human Resource Management Theory and Application. Penerbit Alfabeta. Bandung. 2016.

[2] Ardana, Human Resource Management, Graha Ilmu, Yogyakarta. 2012

[3] Mulyadi. Human Resource Management (MSDM). Bogor: Media. 2015

[4] Anwar Prabu Mangkunegara. Human Resource Management. Company. Bandung: PT. Rosdakarya Teenagers. 2016

[5] Saputro, A. Personnel and Human Resource Management. Yogyakarta: Publisher: BPFE. 2019.

[6] Yazid, ML. Human Resource Management, Student Guidebook, Jakarta: PT. Gramedia Pustaka Utama. 2014.

[7] Busro, Muhammad. Human Resource Management: Ed.I,. Expert,Yogyakarta. 2017.

[8] Kadir,. Human Resource Management for Competitive Business. Yogyakarta: Gajah Mada University Press. 2005.

[9] Hasibuan, Malayu SP. Human Resource Management. PT Bumi Aksara. Jakarta. 2012.

[10] Hidayat, Zainul dan Taufiq.. Human Resource Management. PT. Bumi Aksada. Jakarta. 2012.

[11] Handoko. Human Resource Management. Revised Edition Jakarta Bumi Aksara. 2017.

[12] Priansa, 2016. Planning and Development of Human Resources. Publisher: Alfabeta. Bandung.

[13] Hadinata, A. Human resource management. Edition 14. Salemba. Empat. Jakarta. 2017.

[14] Yusuf, M \& Daris, L. Analysis of Research Data; Theory \& Application in Fisheries. PT. IPB Press. Bogor. 2018.

[15] Ferdinand, Augusty. Management Research Methods: Research Guidelines For Thesis Writing, Thesis and Dissertation on Management Science. Publishing Universitas Diponegoro. Semarang. 2006.

[16] Ghozali, Imam. Multivariate Analysis Application with SPSS Program. BP.UNDIP 2006.

[17] Arifin, Johar. SPSS 24 for Research and Thesis. Jakarta: PT. Elex. Media Komputindo. 2017.

[18] Fahmi, Irham. Human Resource Management. Bandung : Alfabeta. 2017.

[19] Arifin, N. Human Resource Management: Theory and Case. Jepara: UNISNU PRESS. 2017.

[20] Budi, Setiyawan dan Waridin. The Influence of Employee Work Discipline and Organizational Culture on Performance in the Radiology Division of Doctor Kariadi Hospital, Semarang: JRBI. 2006; Vol 2. No 2. Hal:181198

[21] Arlinda, M. Competency-Based Performance Measurement. Jakarta: Rajawali. Pers. 2018.

[22] Nawawi, H. Human Resource Management. Bandung : Alfabeta 2016

[23] Nawawi, H. Hadari. Human Resource Management for Competitive Business. Ed. ke-7, Gadjah Mada University Press, Yogyakarta. 2003

[24] Fathoni, Abdurrahman, Organization and Human Resource Management. Jakarta: PT. Rineka Cipta. 2006.

[25] Justine, T. \& Sirait, Understand aspects of resource management. Humans in organizations. Penerbit PT Grasindo, Jakarta. 2006. 